\title{
Nutritional status and its relationship with different dimensions of functional status in patients with chronic obstructive pulmonary disease
}

\author{
Estado nutricional e sua relação com diferentes \\ dimensões do estado funcional em \\ pacientes com doença pulmonar \\ obstrutiva crônica
}

Fernanda Rodrigues FONSECA ${ }^{1}$

Manuela KARLOH ${ }^{1}$

Cintia Laura Pereira de ARAUJO ${ }^{1}$

Karoliny dos SANTOS ${ }^{1}$

Anamaria Fleig MAYER ${ }^{1}$

A B S T R A C T

\section{Objective}

To investigate whether there is a relationship between nutritional status and limitations in activities of daily living in patients with chronic obstructive pulmonary disease.

\section{Methods}

A cross sectional study was conducted from July to December 2011 in Santa Catarina. Seventeen chronic obstructive pulmonary disease patients [age (years) $=67 \pm 8$; forced expiratory volume in one second (\% of the predicted value $=38.6 \pm 16.1$; body mass index $\left(\mathrm{kg} / \mathrm{m}^{2}\right)=24.7 \pm 5.4$ ] underwent the assessments: pulmonary function (spirometry); functional status (London Chest Activity of Daily Living scale, physical activities in daily life, and Glittre ADL-Test; nutritional status (anthropometry and dual-energy X-Ray absorptiometry).

\section{Results}

The total score of the London Chest Activity of Daily Living scale correlated with fat-free mass $(r=-0.50 ; p=0.04)$ and lean mass $(r=-0.50 ; p=0.04)$. The lying time in physical activities in daily life correlated with bone mineral content $(r=-0.50 ; p=0.04)$. Nutricional status was not correlated with time spent on Glittre ADL-test.

\footnotetext{
${ }^{1}$ Universidade do Estado de Santa Catarina, Programa de Pós-Graduação em Fisioterapia, Núcleo de Assistência, Ensino e Pesquisa em Reabilitação Pulmonar. R. Pascoal Simone, 358, Coqueiros, 88080-350, Florianópolis, SC, Brasil. Correspondência para/Correspondence to: AF MAYER. E-mail: <annafmayer@gmail.com>.
} 


\section{Conclusion}

Variables that reflect muscle mass depletion are related to variables of self-reported limitation in activities of daily living. Bone mineral content is correlated with time patients spend lying, reflecting the impact of inactive postures on the nutritional status of these patients.

Keywords: Activities of daily living. Evaluation. Chronic obstructive pulmonary disease. Nutricional status.

\section{R E S U M O}

\section{Objetivo}

Investigar se existe relação entre o estado nutricional e a limitação em atividades de vida diária em pacientes com doença pulmonar obstrutiva crônica.

\section{Métodos}

Um estudo transversal foi conduzido de julho a dezembro de 2011 em Santa Catarina. Dezessete pacientes com doença pulmonar obstrutiva crônica [idade (anos) $=67 \pm 8$; volume expiratório forçado no primeiro segundo (\% do valor predito) $=38,6 \pm 16,1$; índice de massa corporal $\left.\left(\mathrm{kg} / \mathrm{m}^{2}\right)=24,7 \pm 5,4\right]$ foram submetidos à avaliação da função pulmonar (espirometria); do estado funcional (escala London Chest Activity of Daily Living, monitorização das atividades físicas na vida diária e teste de AVD-Glittre); e do estado nutricional (antropometria e absorciometria por dupla emissão de Raios X).

\section{Resultados}

O escore total da escala London Chest Activity of Daily Living correlacionou-se negativamente com a massa livre de gordura $(r=-0,50 ; p=0,04)$ e com a massa magra $(r=-0,50 ; p=0,04)$. O tempo deitado nas atividades físicas na vida diária apresentou correlação negativa com o conteúdo mineral ósseo $(r=-0,50 ; p=0,04)$. Não foram encontradas correlações significativas entre variáveis de estado nutricional e tempo despendido no TGlittre.

\section{Conclusão}

Variáveis que refletem a depleção muscular estão relacionadas a variáveis de autorrelato de limitação em atividades de vida diária. O conteúdo mineral ósseo correlaciona-se ao tempo que os pacientes permanecem deitados, refletindo o impacto de posturas inativas no estado nutricional desses indivíduos.

Palavras-chave: Atividades cotidianas. Avaliação. Doença pulmonar obstrutiva crônica. Estado nutricional

\section{INTRODUCTION}

Chronic Obstructive Pulmonary Disease (COPD) is associated with pulmonary and systemic manifestations, such as nutritional abnormalities and skeletal muscle dysfunction ${ }^{1}$ - which have an impact on patients' exercise capacity and on their ability to perform Activities of Daily Living $(A D L)^{2}$.

Among the nutritional abnormalities, the most common clinical manifestation is weight loss, especially related to muscle mass, which is particularly prevalent in more severe patients. Even in the absence of weight loss, the body composition of COPD patients present significant differences ${ }^{3,4}$. These changes in body composition are justified by factors like age, inflammation, oxidative stress, hypoxemia, hypercapnia, low levels of anabolic hormones and growth factors, impaired energy balance, corticosteroid use, vitamin $D$ deficiency, and peripheral muscle disuse ${ }^{5}$.

Chronic obstructive pulmonary disease patients experience limitations in $A D L$, which lead to complaints of dyspnea and fatigue ${ }^{6}$. Thus, COPD patients start to avoid physical activities that trigger those symptoms, becoming increasingly deconditioned and less physically active $^{2}$. Considering that physical exercise can act as an anabolic stimulus in COPD patients ${ }^{7}$, low level of physical activity may exacerbate the imbalance between anabolism and catabolism, further reducing the muscle mass of these patients. 
The relationship between nutritional status and exercise tolerance in COPD patients has been evidenced by the association of anthropometric and body composition variables with performance variables in maximum ${ }^{8-10}$ and submaximal ${ }^{11,12}$ exercise tests. However, the relationship between nutritional status and dimensions of functional status, such as functional capacity (people's maximum potential to perform activities in the normal course of their lives $)^{13}$ and functional performance (activities that people actually perform in the normal course of their lives) ${ }^{13}$, evaluated by specific tests to assess limitations in $A D L$, has been little explored. Based on the above, this study aims to investigate the relationship between nutritional status and limitation in ADL in COPD assessed by instruments covering different dimensions of functional status.

\section{Methods}

A cross sectional study was conducted from July to December 2011 in Florianópolis Santa Catarina. The study included patients with moderate to very severe COPD, of both genders, clinically stable during the previous month to the beginning of the study protocol, aged over 40 years, and with smoking history $\geq 20$ pack-years. Patients unable to perform any part of the study protocol, currently smoking, or having other diseases - such as cardiomyopathy, musculoskeletal diseases, cancer, tuberculosis, asthma - were excluded. A total of 32 clinically stable patients from the pulmonology outpatient services of public hospitals and private clinics were invited to participate in the study. Twelve of the 32 declined to take part in the study and 20 agreed to participate. Seventeen patients completed the study and 3 were excluded: 2 due to inability to perform the proposed tests, and one for restarting to smoke during the protocol. The research was approved by the Universidade Estadual Santa Catarina (State University of Santa Catarina) Human Research Ethics Committee under the reference $n^{\circ} 85 / 2010$.

\section{Pulmonary function testing}

Pulmonary function was tested by a spirometer (EasyOne, NDD Medical Technologies ${ }^{\circledR}$, Andover, Massachusetts, USA), whose calibration was checked before the evaluations. Spirometry was performed in accordance with the American Thoracic Society/European Respiratory Society (ATS/ERS) standards ${ }^{14}$. The Post-Bronchodilator $(\mathrm{BD})$ variables Forced Expiratory Volume in One Second $\left(\mathrm{FEV}_{1}\right)$, in Liters $(\mathrm{L})$, and in percentage of the predicted value (\% pred), Forced Vital Capacity (FVC), also in $\mathrm{L}$ and in \%pred, and their ratio ( $\mathrm{FEV}_{1} /$ FVC) were included. The post-BD FEV $/$ FVC and $\mathrm{FEV}_{1}$ in \%pred were used to identify airflow limitation and to classify it (mild, moderate, severe, or very severe $)^{15}$. The predicted values were calculated from the equations proposed by Pereira et al. ${ }^{16}$ for Brazilians.

\section{Functional Status}

The London Chest Activity of Daily Living (LCADL) scale, validated for Brazilian Portuguese, consists of ordinary ADL divided into four domains (personal care, household activities, physical activities, and leisure), which are arranged in 15 quantitative items for a maximum score of 75 points. The total LCADL score and percentage of the total LCADL score (LCADL \% total score) were calculated ${ }^{17}$.

The Physical Activities in Daily Life (PADL) were monitored by a triaxial accelerometer (DynaPort Activity Monitor, McRoberts BV ${ }^{\circledR}$, The Hague, The Netherlands), which measures the time in minutes (min) spent standing, sitting, lying, and walking, and movement intensity during walking, in meters per second squared $\left(\mathrm{m} / \mathrm{s}^{2}\right)$. The participants were monitored for two consecutive week days for 12 hours after awakening. All patients received thorough instructions on equipment use, an explanatory and illustrated manual, and a diary to record monitoring times and difficulties. Patients were instructed not to change their usual activities while using the device ${ }^{2}$. The MIRA $2^{\text {nd }}$ version software (DynaPort 
Activity Monitor, McRoberts BV ${ }^{\circledR}$, The Hague, The Netherlands) processed the collected data.

The Glittre ADL-test (TGlittre) consists of completing a circuit while carrying a weighted backpack (2.5 kg for women, $5.0 \mathrm{~kg}$ for men). The circuit is as follows: from a sitting position, the patient stands up and walks along a flat 10-m long course; in the middle of which is a two-step staircase (each step $17 \mathrm{~cm}$ high $\times 27$ $\mathrm{cm}$ deep) to be traversed; after completing the second $5 \mathrm{~m}$, the subject faces a shelf containing three objects, each weighing $1 \mathrm{~kg}$, positioned on the top shelf (shoulder height) and moves them one by one to the bottom shelf (waist height) and then to the floor; the objects are then returned to the bottom shelf and finally to the top shelf again; the patient then walks back along the circuit, climbing the stairs up and down, until reaching the starting point (chair); sitting down and immediately beginning the next lap. Patients were instructed to complete five laps on this circuit as quickly as possible ${ }^{18}$. Heart Rate (HR monitor FS2C, Polar ${ }^{\circledR}$, Finland), Saturation of Peripheral Oxygen (SpO2) (Oxi-Go, Oximeter Plus ${ }^{\circledR}$, New York, New York, USA) and index of dyspnea (modified Borg scale) were measured at the beginning, at every turn, and at the end of the test. The test was performed in the absence of verbal stimuli.

\section{Nutritional Status}

Patients used nothing but an apron during nutritional status assessment. Weight in kilograms $(\mathrm{kg})$ was measured by a scale accurate to $100 \mathrm{~g}$ (BC-558 Ironman, Tanita Corporation ${ }^{\circledR}$, Tokyo, Japan). Height in meters $(m)$ was measured by stadiometer with accuracy of $0.1 \mathrm{~cm}$ (Standard, Sanny ${ }^{\circledR}$, São Bernardo do Campo, São Paulo, Brazil). Body Mass Index (BMI) was calculated by dividing weight by the square of the height $\left(\mathrm{kg} / \mathrm{m}^{2}\right)^{19}$.

Body composition was assessed by Dual Energy X-Ray Absorptiometry (DEXA), which is based on the differential attenuation of $X$-Rays between body tissues ${ }^{20}$. Dual energy X-Ray absorptiometry whole body scan was performed with the patients in the supine position by a medical radiology technician certified by the Brazilian Society of Clinical Densitometry. Bone density was measured by a bone densitometer (Lunar Prodigy Advance, GE Medical Systems Lunar $^{\circledR}$, Diegem, Belgium), calibrated as instructed by the manufacturer and the software Prodigy encore v.12.30 (GE Medical Systems Lunar ${ }^{\circledR}$, Diegem, Belgium). The included variables were fat mass, Bone Mineral Content (BMC), Lean Mass (LM), and Fat-Free Mass (FFM - consisting of the sum of $\mathrm{LM}$ and $\mathrm{BMC}^{21}$ ) in $\mathrm{kg}$; and Fat-Free Mass Index (FFMI), calculated by the dividing FFM in $\mathrm{kg}$ by the square of the height in meters ${ }^{22}$.

The body mass index and fat-free mass index were used for detecting depletion of body weight and FFM and for categorizing patients into cachexia, semi-starvation, muscle atrophy, and no impairment of body composition ${ }^{23}$. Body mass index was also used for classifying overweight and obesity $^{19}$.

\section{Statistical Analysis}

The Shapiro-Wilk test was used, along with the parametric (Pearson) or nonparametric (Spearman) correspondent test according to data distribution. The data were summarized using the Statistical Package for the Social Sciences version 20.0 (SPSS, IBM ${ }^{\circledR}$, Somers, New York, USA). The significance level for the statistical treatment was $5 \%(p<0.05)$.

\section{RES ULTS}

Seventeen patients (14 men) with moderate $(n=4)$, severe $(n=6)$, and very severe $(n=7)$ airflow limitation were included in the study. Sixteen patients were treated with $\beta 2$ agonists, and 9 with anticholinergics. Table 1 shows the sample characteristics.

In the functional status assessment, the average time spent in TGlittre varied between $4.20 \mathrm{~min}(4 \mathrm{~min}$ and $12 \mathrm{~s}$ ) and $5.83 \mathrm{~min}(5 \mathrm{~min}$ and $50 \mathrm{~s}$ ). The average LCADL total score ranged 
from 14.4 to 21.5 points while the LCADL \%total score from 22.3 to 33. Regarding PADL, patients spent an average of $67.4 \pm 10.7 \%$ of monitored time in sedentary positions (lying or sitting) and $31.2 \pm 9.5 \%$ of the time in active positions (standing or walking). Table 1 describes the functional status variables.

Six patients had body weight depletion, 5 were overweight, and 3 were obese. Depletion of FFM was present in 4 patients. Two patients presented semi-starvation, 4 presented cachexia, and the others had no impairment of body composition. Table 1 provides the nutritional status variables.

The LCADL total score was negatively correlated with FFM $(r=-0.50, p=0.04)$ and LM $(r=-0.50, p=0.04)$. Lying time in PADL was negatively correlated with BMC $(r=-0.50, p=0.04)$, and the latter was correlated with BMI $(r=0.62$, $p=0.007)$ but not with age. No other PADL correlated with nutritional status. No significant correlations between nutritional status variables and time spent in TGlittre were found. Figure 1 shows the correlations.

\section{DISCUSSION}

The present study was able to show correlations between body composition variables, related to muscle and bone mass, and functional performance variables, however, no significant correlations between the variables of nutritional status and functional capacity could be observed.

Low level of physical activity in daily living may worsen the imbalance between muscle anabolism and catabolism, and influence the functional status of COPD patients. In this context, functional performance may reflect more appropriately LM and BMC as it regards the activities that individuals actually perform in everyday life and reveal how individuals are active.

Table 1. Sample characteristics, and functional and nutritional statuses.

\begin{tabular}{|c|c|c|c|c|c|}
\hline \multirow{2}{*}{ Variables } & \multirow{2}{*}{ Mean } & \multirow{2}{*}{ SD } & \multirow{2}{*}{ Median } & \multicolumn{2}{|c|}{$95 \% \mathrm{Cl}$} \\
\hline & & & & LL & UL \\
\hline Age (years) & 67 & 8 & & 63.0 & 71.00 \\
\hline Smoking history (pack-years) & & & 50.00 & 24.0 & 74.00 \\
\hline $\mathrm{FEV}_{1} / \mathrm{FVC}$ & 0.45 & 0.11 & & 0.39 & 0.51 \\
\hline $\mathrm{FEV}_{1}(\mathrm{~L})$ & 1.17 & 0.49 & & 0.92 & 1.42 \\
\hline $\mathrm{FEV}_{1}$ (\%pred) & 38.70 & 16.1 & & 30.4 & 46.90 \\
\hline $\mathrm{FVC}(\mathrm{L})$ & 2.63 & 0.61 & & 2.21 & 2.84 \\
\hline FVC (\%pred) & 64.50 & 16.0 & & 56.2 & 72.70 \\
\hline LCADL (points) & & & 18.00 & 13.0 & 21.00 \\
\hline LCADL (\%total score) & 27.70 & 10.4 & & 22.3 & 33.00 \\
\hline Lying time $(\mathrm{min})^{\#}$ & & & 76.00 & 0 & 143.50 \\
\hline Sitting time (min) & 394.90 & 93.6 & & 346.7 & 443.00 \\
\hline Standing time $(\mathrm{min})^{\#}$ & & & 130.00 & 112.0 & 163.50 \\
\hline Walking time $(\mathrm{min})^{\#}$ & & & 68.00 & 57.5 & 87.00 \\
\hline Movement intensity $\left(\mathrm{m} / \mathrm{s}^{2}\right)$ & 1.81 & 0.30 & & 1.65 & 1.96 \\
\hline TGlittre $(\min )^{\#}$ & & & 4.67 & 3.97 & 5.47 \\
\hline BMI $\left(\mathrm{kg} / \mathrm{m}^{2}\right)$ & 24.70 & 5.40 & & 21.9 & 27.50 \\
\hline $\mathrm{FM}(\mathrm{kg})$ & 20.70 & 9.37 & & 15.9 & 25.60 \\
\hline $\mathrm{BMC}(\mathrm{kg})$ & 2.43 & 0.46 & & 2.19 & 2.66 \\
\hline LM (kg) & 48.30 & 8.16 & & 44.1 & 52.50 \\
\hline FFM (kg) & 50.70 & 8.53 & & 46.3 & 55.10 \\
\hline FFMI $\left(\mathrm{kg} / \mathrm{m}^{2}\right)$ & 18.80 & 2.88 & & 17.3 & 20.30 \\
\hline
\end{tabular}

Note: "Median and interquartile range (25\% - 75\%); \%Pred: Percentage of the Predicted value; \%total: percentage of LCADL: London Chest Activity of Daily Living scale; \%total: percentage of LCADL total score; SD: Standard Deviation; CI: Confidence Interval; LL: Lower Limit; UL: Upper Limit; FEV : Forced Expiratory Volume in 1 s; FVC: Forced Vital Capacity; LCADL: London Chest Activity of Daily Living scale; TGlittre: Glittre ADL-test; BMI: Body Mass Index; BMC: Bone Mineral Content; FM: Fat Mass; LM: Lean Mass; FFM: Fat-Free Mass; FFMI: Fat-Free Mass Index. 


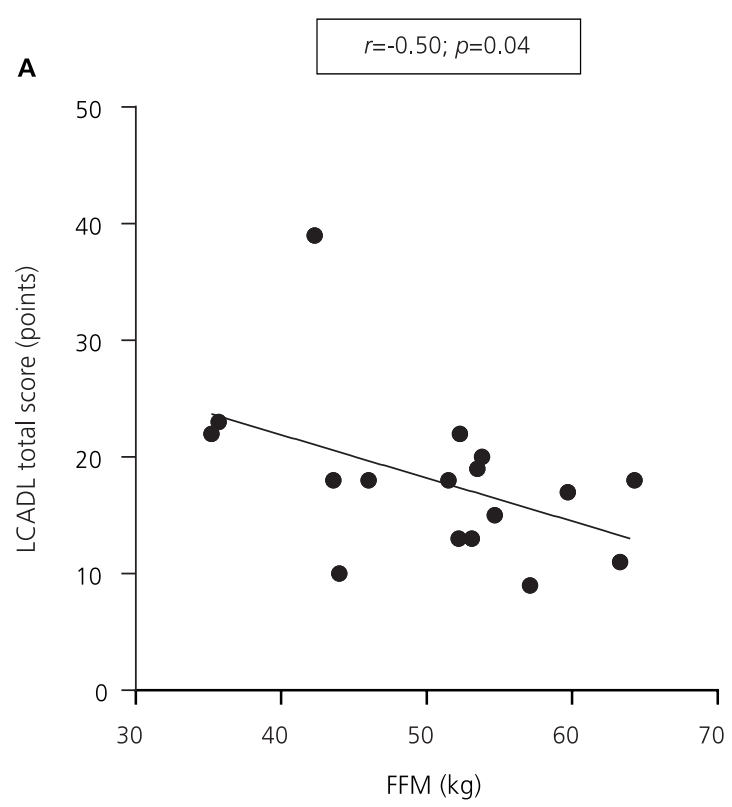

FFM (kg)

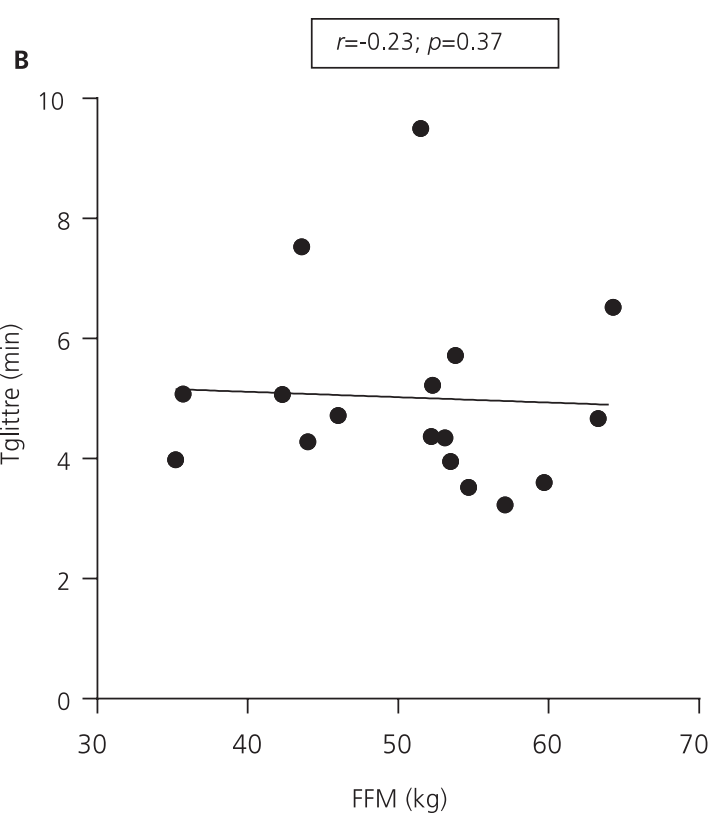

$r=0.27 ; p=0.29$

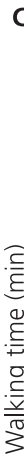

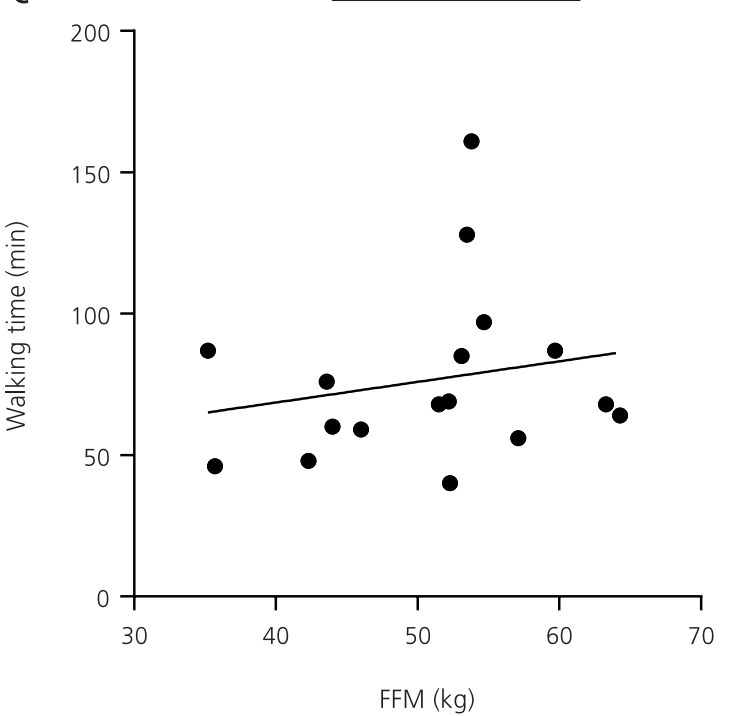

Figure 1. Correlation between Fat-Free Mass (FFM) and (A) London Chest Activity of Daily Living (LCADL) scale total score; (B) Time spent in Glittre ADL-test (TGlittre); (C) walking time.

The associations of BMI with peak work rate $^{10}$, peak workload ${ }^{9}$, oxygen uptake at peak ${ }^{8,9}$, and oxygen uptake at anaerobic threshold ${ }^{8}$ have already been demonstrated. Also, FFM was a determining factor of peak workload and oxygen uptake at peak ${ }^{9}$, suggesting the influence of nutritional status on muscle aerobic capacity and exercise tolerance in COPD patients. Furthermore, depletion of FFM has been identified as an important negative factor for the functional capacity of COPD patients, regardless of $\mathrm{FEV}_{1}{ }^{24}$.

Pulmonary function alone has not been considered a good predictor of nutritional status ${ }^{3}$ and functional performance in these patients ${ }^{2}$. 
The study patients had severe impairment of lung function (13 patients with severe or very severe airflow limitation). Notwithstanding, they presented no significant impairment of body composition, and nutritional depletion was observed in only 6 of the 17 patients. Additionally, these patients had less functional impairment than Brazilian patients from other studies $17,25,26$. The present patients were more active than those of other studies; walked more (on average $76.4 \mathrm{~min} /$ day vs. $55 \mathrm{~min} /$ day $)^{25}$, and spent less time lying (mean 84.4 vs 119 min/day) ${ }^{26}$ during their PADL. In addition, patients had an average LCADL $\%$ total score of less than 50 , indicating that those patients were possibly only slightly limited in their functional status ${ }^{27}$.

The relationship between $L C A D L$ and nutritional status has been analyzed previously27, but it only included BMI. The present study found correlations of LCADL total score with LM and FFM. Indeed, functional limitation is strongly related to muscle wasting and reduced muscle mass $^{11,12,24}$. This means that LCADL total score is sensitive to detect this relationship.

Despite everything, an ADL multiple-task test, such as the TGlittre, had not yet been used to investigate this relationship. Previous studies that sought to assess the functional capacity of COPD patients by Six-Minute Walk Test (6MWT) found that BMI and FFMI were positively correlated with the distance covered in this test $11,12,24$. However, the present study found no correlations between nutritional status variables and time spent in TGlittre, which mimics the situations experienced in ADL with a set of common activities of daily living, generally limited in COPD patients. But it is worth noting that the authors who validated the TGlittre suggested that the test may not discriminate patients with lower functional limitation well ${ }^{18}$, a factor that may have contributed to the absence of correlations.

In the physical activities in daily life analysis, the study patients spent most of the monitored time in sedentary postures. Nevertheless, this time was still lower than times reported by previous studies $^{2,25}$. Moreover, BMC and the time the study patients spent lying were negatively correlated.

Physical inactivity is a risk factor for low Bone Mineral Density (BMD), as well as higher age, smoking, low BMI, systemic inflammation, pulmonary dysfunction, glucocorticoid use, and vitamin D insufficiency/deficiency ${ }^{28}$. Besides the correlation between BMC and physical inactivity, the present study also found a correlation between $\mathrm{BMC}$ and $\mathrm{BMI}$, but not between bone mineral content and age. Bone is a biomechanical tissue that adapts its structure to withstand varying forces stemming from muscle activity and gravity ${ }^{29}$. The relationship between physical activity, objectively measured by triaxial accelerometers, and BMD has been described in both healthy older adults ${ }^{30}$ and in COPD patients ${ }^{31}$. In healthy older adults, a positive association was found between moderate to vigorous physical activity and femoral neck $\mathrm{BDM}^{30}$. Moreover, COPD patients with osteoporosis had lower level of daily physical activity than those without COPD, and daily physical activity correlated positively with lumbar spine, total hip, and femoral neck $B M D^{31}$.

This study found no other correlations between PADL and nutritional status variables. Pitta et al. ${ }^{2}$, studying the PADL of COPD patients, also found no correlation between $\mathrm{BMI}$ and monitored standing or walking time. In turn Monteiro et al..$^{32}$ found that monitored time spent in at least moderate-intensity activities correlated with body weight, BMI, and FM, but not with FFM. Likewise, Waschki et al. ${ }^{33}$ found that patients with sustained physical inactivity for 3 years had greater FFM decrease than patients with some level of physical activity, regardless of $\mathrm{FEV}_{1}$.

Assessment of body composition can be performed by direct (dissection of cadavers), indirect (hydrostatic weighing, DEXA), and doubly indirect (anthropometry and bioelectrical impedance analysis) methods. In this context DEXA - method used in this study - has the potential to provide overall and regional assessment of body composition in terms of fat, lean, and bone masses ${ }^{20}$. Many studies that set 
out to analyze body composition did so based only on data obtained from simple BMI calculation. Although BMI is the most commonly used indicator, it does not provide clear information about the distribution of lean mass or fat-free mass.

Patients were not classified based on the presence of emphysema (lean look and significant weight loss) or chronic bronchitis (obese or without marked weight loss) since it is often difficult to distinguish these overlapping phenotypes. Furthermore, the small percentage of malnourished patients may be explained by the fact that only three of them were female, and COPD women have a higher prevalence of nutritional depletion than their male counterparts $^{3}$. Nutritional and functional impairments begin early in this population. COPD patients reduce their physical activity early, before the onset of breathlessness ${ }^{34}$. Additionally, even older symptomatic smokers who do not meet the diagnostic criteria for COPD present nutritional deficits $^{35}$.

The patients' nutritional and functional characteristics may have compromised the strength of the study correlations. The relationship between nutritional status and functional status measured by TGlittre may be more evident in patients with greater functional impairment since the test appears to be less discriminatory in patients with fewer limitations in ADL. The study power was calculated based on the correlation coefficient ( $r$ ) of LCADL total score with FFM and LM ( $r=-0.50$ for both). With the present sample and $\alpha=0.010$, the power to detect the relationship between functional and nutritional limitations was $80 \%$.

In despite of its strengths, some limitations of this study should be made clear. Although the sample size was sufficient, a relatively small number of patients, especially women, were included in the study. This prevented gender comparisons, even though it was not the aim of this study. In spite of this, the results were consistent and thereby, seem to be representative for this group. The statistical power for the analysis was $80 \%$.

This appears to be the first study to investigate the relationship between nutritional and functional statuses using specific tools validated for COPD for assessing limitations in $\mathrm{ADL}$. The understanding of this relationship can guide interdisciplinary therapeutic approaches that aim to improve those two outcomes, such as pulmonary rehabilitation, optimizing COPD prognosis.

In summary, in patients with moderate to very severe COPD, nutritional status variables reflecting muscle mass correlate with variables of self-reported limitations in ADL. Bone Mineral Content correlates with the daily time patients spend lying, reflecting the impact of inactive positions on their nutritional status. Further studies are needed to investigate the relationship between nutritional and functional statuses in COPD patients with greater nutritional depletion and functional limitations.

\section{REFERE N CES}

1. Choudhury G, Rabinovich R, MacNee W. Comorbidities and systemic effects of chronic obstructive pulmonary disease. Clin Chest Med. 2014; 35(1):101-30. http://dx.doi.org/10.1016/j. $\mathrm{ccm} .2013 .10 .007$

2. Pitta F, Troosters T, Spruit MA, Probst VS, Decramer M, Gosselink R. Characteristics of physical activities in daily life in chronic obstructive pulmonary disease. Am J Respir Crit Care Med. 2005; 171(9):972-7. http://dx.doi.org/10.1164/rccm. 200407-8550C

3. Vermeeren MA, Creutzberg EC, Schols AM, Postma DS, Pieters WR, Roldaan AC, et al. Prevalence of nutritional depletion in a large out-patient population of patients with COPD. Respir Med. 2006; 100(8):1349-55. http://dx.doi.org/10.1016/ j.rmed.2005.11.023

4. Humphreys K, Cross G, Frith P, Cafarella P. Nutritional status and dietary intake of outpatients with chronic obstructive pulmonary disease. Nutr Diet. 2008; 65(2):168-74. http://dx.doi.org/10.1111/j.1747-00 80-2008.00235.x

5. Maltais F, Decramer M, Casaburi R, Barreiro E, Burelle $Y$, Debigare $R$, et al. An official American Thoracic Society/European Respiratory Society 
statement: Update on limb muscle dysfunction in chronic obstructive pulmonary disease. Am J Respir Crit Care Med. 2014; 189(9):e15-62. http://dx.doi. org/10.1164/rccm.201402-0373ST

6. Lahaije AJ, van Helvoort HA, Dekhuijzen PN, Heijdra YF. Physiologic limitations during daily life activities in COPD patients. Respir Med. 2010; 104(8):1152-9. http://dx.doi.org/10.1016/j.rmed.2010.02.011

7. Franssen FM, Broekhuizen R, Janssen PP, Wouters EF, Schols AM. Effects of whole-body exercise training on body composition and functional capacity in normal-weight patients with COPD. Chest. 2004; 125(6):2021-8.

8. Lan CC, Su CP, Chou LL, Yang MC, Lim CS, Wu YK. Association of body mass index with exercise cardiopulmonary responses in lung functionmatched patients with chronic obstructive pulmonary disease. Heart Lung. 2012; 41(4):374-81. http://dx. doi.org/10.1016/j.hrtlng.2012.02.010

9. Aiello M, Teopompi E, Tzani P, Ramponi S, Gioia $M R$, Marangio $E$, et al. Maximal exercise in obese patients with COPD: The role of fat free mass. BMC Pulm Med. 2014; 14:96. http://dx.doi.org/10.1186/ 1471-2466-14-96

10. Galesanu RG, Bernard S, Marquis K, Lacasse Y, Poirier P, Bourbeau J, et al. Obesity in chronic obstructive pulmonary disease: Is fatter really better? Can Respir J. 2014; 21(5):297-301.

11. Sabino PG, Silva BM, Brunetto AF. Nutritional status is related to fat-free mass, exercise capacity and inspiratory strength in severe chronic obstructive pulmonary disease patients. Clinics. 2010; 65(6):599-605. http://dx.doi.org/10.1590/s1807-5 9322010000600007

12. Luo Y, Zhou L, Li Y, Guo S, Li X, Zheng J, et al. FatFree Mass Index for Evaluating the Nutritional Status and Disease Severity in COPD. Respir Care. 2016; 61(5):680-8. http://dx.doi.org/10.4187/respcare. 04358

13. Leidy NK. Using functional status to assess treatment outcomes. Chest. 1994; 106(6):1645-6.

14. Miller MR, Hankinson J, Brusasco V, Burgos F, Casaburi R, Coates A, et al. Standardisation of spirometry. Eur Respir J. 2005; 26(2):319-38. http:// dx.doi.org/10.1183/09031936.05.00034805

15. Global Strategy for the Diagnosis, Management and Prevention of COPD, Global Initiative for Chronic Obstructive Lung Disease. Gold. 2016 [cited 2016 May 4]. Available from: http://goldcopd.org/

16. Pereira CA, Sato T, Rodrigues SC. New reference values for forced spirometry in white adults in Brazil. J Bras Pneumol. 2007; 33(4):397-406.

17. Carpes MF, Mayer AF, Simon KM, Jardim JR, Garrod $R$. The Brazilian Portuguese version of the London
Chest Activity of Daily Living scale for use in patients with chronic obstructive pulmonary disease. J Bras Pneumol. 2008; 34(3):143-51.

18. Skumlien S, Hagelund T, Bjortuft O, Ryg MS. A field test of functional status as performance of activities of daily living in COPD patients. Respir Med. 2006; 100(2):316-23. http://dx.doi.org/10.1016/j.rmed. 2005.04.022

19. Worl Health Organization. Physical status: The use and interpretation of anthropometry. Report of a WHO Expert Committee. Geneva: WHO; 1995. Technical Report Series, 854.

20. Andreoli A, Scalzo G, Masala S, Tarantino U, Guglielmi G. Body composition assessment by dualenergy X-Ray absorptiometry (DXA). Radiol Med. 2009; 114(2):286-300. http://dx.doi.org/10.1007/ s 11547-009-0369-7

21. Engelen MP, Schols AM, Heidendal GA, Wouters EF. Dual-energy X-Ray absorptiometry in the clinical evaluation of body composition and bone mineral density in patients with chronic obstructive pulmonary disease. Am J Clin Nutr. 1998; 68(6):1298-303.

22. Vanltallie TB, Yang MU, Heymsfield SB, Funk RC, Boileau RA. Height-normalized indices of the body's fat-free mass and fat mass: Potentially useful indicators of nutritional status. Am J Clin Nutr. 1990; 52(6):953-9.

23. Schols AM, Broekhuizen R, Weling-Scheepers CA, Wouters EF. Body composition and mortality in chronic obstructive pulmonary disease. Am J Clin Nutr. 2005; 82(1):53-9.

24. Ischaki E, Papatheodorou G, Gaki E, Papa I, Koulouris $\mathrm{N}$, Loukides S. Body mass and fat-free mass indices in COPD: Relation with variables expressing disease severity. Chest. 2007; 132(1):164-9. http:/dx. doi.org/10.1378/chest.06-2789

25. Hernandes NA, Teixeira DC, Probst VS, Brunetto AF, Ramos EM, Pitta F. Profile of the level of physical activity in the daily lives of patients with COPD in Brazil. J Bras Pneumol. 2009; 35(10):949-56.

26. Pitta F, Breyer MK, Hernandes NA, Teixeira D, Sant'Anna TJ, Fontana AD, et al. Comparison of daily physical activity between COPD patients from Central Europe and South America. Respir Med. 2009; 103(3):421-6. http://dx.doi.org/10.1016/j. rmed.2008.09.019

27. Simon KM, Carpes MF, Correa KS, Santos K, Karloh M, Mayer AF. Relationship between daily living activities (ADL) limitation and the BODE index in patients with chronic obstructive pulmonary disease. Rev Bras Fisioter. 2011; 15(3):212-8.

28. Inoue D, Watanabe R, Okazaki R. COPD and osteoporosis: Links, risks, and treatment challenges. 
Int J Chron Obstruct Pulmon Dis. 2016; 11:637-48. http://dx.doi.org/10.2147/copd.s79638

29. Laurent MR, Dubois V, Claessens F, Verschueren SM, Vanderschueren D, Gielen E, et al. Muscle-bone interactions: From experimental models to the clinic? A critical update. Mol Cell Endocrinol. 2015. http://dx.doi.org/10.1016/j.mce.2015.10.017

30. Johansson J, Nordstrom A, Nordstrom P. Objectively measured physical activity is associated with parameters of bone in 70-year-old men and women. Bone. 2015; 81:72-9. http://dx.doi.org/10. 1016/j.bone.2015.07.001

31. Liu WT, Kuo HP, Liao TH, Chiang LL, Chen LF, Hsu $M F$, et al. Low bone mineral density in COPD patients with osteoporosis is related to low daily physical activity and high COPD assessment test scores. Int J Chron Obstruct Pulmon Dis. 2015; 10:1737-44. http://dx.doi.org/10.2147/copd.s87 110

32. Monteiro F, Camillo CA, Vitorasso R, Sant'Anna T, Hernandes NA, Probst VS, et al. Obesity and physical activity in the daily life of patients with COPD. Lung. 2012; 190(4):403-10. http://dx.doi.org/10.1007/s0 0408-012-9381-0
33. Waschki B, Kirsten AM, Holz O, Mueller KC, Schaper M, Sack AL, et al. Disease Progression and Changes in Physical Activity in Patients with Chronic Obstructive Pulmonary Disease. Am J Respir Crit Care Med. 2015; 192(3):295-306. http://dx.doi. org/10.1164/rccm.201501-00810C

34. Gouzi F, Prefaut C, Abdellaoui A, Vuillemin A, Molinari N, Ninot $G$, et al. Evidence of an early physical activity reduction in chronic obstructive pulmonary disease patients. Arch Phys Med Rehabil. 2011; 92(10):1611-7.e2. http://dx.doi.org/10.1016/j. apmr.2011.05.012

35. Obase Y, Mouri K, Shimizu H, Ohue Y, Kobashi Y, Kawahara $\mathrm{K}$, et al. Nutritional deficits in elderly smokers with respiratory symptoms that do not fulfill the criteria for COPD. Int J Chron Obstruct Pulmon Dis. 2011; 6:679-83. http://dx.doi.org/ 10.2147/copd.s25293

Received: December 9, 2015 Final version: May 18, 2016 Approved: June 17, 2016 